\title{
Translating orthopaedic basic science into clinical relevance
}

Henning Madry

\begin{abstract}
In orthopaedic and trauma surgery, the rapid evolution of biomedical research has fundamentally changed the perception of the musculoskeletal system. Here, the rigor of basic science and the art of musculoskeletal surgery have come together to create a new discipline -experimental orthopaedics- that holds great promise for the causative cure of many orthopaedic conditions. The Journal of Experimental Orthopaedics intends to bridge the gap between orthopaedic basic science and clinical relevance, to allow for a fruitful clinical translation of excellent and important investigations in the field of the entire musculoskeletal system.
\end{abstract}

Keywords: Basic science; Orthopaedics; Translation; Clinics

The essence of life science is to systematically describe the way organisms live. In the orthopaedic field, the rapid evolution of biomedical research during the past 30 years has changed fundamentally the way we think about the musculoskeletal system in health and disease. For example, while menisci were once thought to be functionless remnants of intra-articular leg muscles [1], it is now clear that these unique fibrocartilaginous structures have distinct functions, and multiple and serious efforts are devoted by orthopaedic sports medicine surgeons, biomaterial scientists, cell, molecular, and developmental biologists, biochemists, biotechnologists, and biomechanical engineers to preserve and to regenerate meniscal tissue [2-19] as a way to halt the initiation and progression of osteoarthritis [20,21]. Here, the art of musculoskeletal surgery and the rigor of basic science have come together to create a new discipline - experimental orthopaedics - that holds great promise for the causative cure of many musculoskeletal conditions that are not only disabling such as osteoarthritis, but are also life-threatening as the many bone and soft tissue tumours.

The founders of the Journal of Experimental Orthopaedics - the board of ESSKA, the European Society of Sports Traumatology, Knee Surgery and Arthroscopy recognized the need to establish a scientific journal that would publish basic science reports of new and

Correspondence: henning.madry@uks.eu

Center of Experimental Orthopaedics, Saarland University, Homburg/Saar D-66421, Germany

\section{Springer}

(C) 2014 Madry; licensee Springer. This is an Open Access article distributed under the terms of the Creative Commons Attribution License (http://creativecommons.org/licenses/by/4.0), which permits unrestricted use, distribution, and reproduction in any medium, provided the original work is properly cited. important investigations in the field of the entire musculoskeletal system with a view of translating them into clinical reality. ESSKA hosts bi-annual congresses, with an ever-growing number of participants and presentations of high scientific quality. Of note, ESSKA has a long tradition of supporting basic science, highlighted in the prestigious Theo van Rens Award for the best scientific presentation, named after Professor Theo J. G. van Rens (1931-1986), one of the founding members of ESSKA [22]. The Journal of Experimental Orthopaedics intends to bridge the gap between orthopaedic basic science and clinics. Its goal is to publish papers related to the entire field of experimental orthopaedics, including physiological, pathological, and therapeutic aspects of cartilage, bone, tendons, ligaments, and other musculoskeletal tissues. Scientific excellence is the main criterion for publication. Another basic principle is to provide a peer review process that is both decisive and fair to authors, with a focus of a fast turnaround time. As we believe that the results of scientific research should be freely available to everyone to read and use, we have chosen an open access model, which is, among others, supported by such highly prestigious organizations such as the European Commission, the Howard Hughes Medical Institute, the Max Planck Society, the National Institutes of Health and the Wellcome Trust. The international Journal of Experimental Orthopaedics will 
thus enable clinicians and scientists to better work together in order to take a leading role in the publication of research in a way that is without restricted access to these results.

At the Journal of Experimental Orthopaedics, our goal is to put high quality basic science first, as the editorial decision making process is not driven by profits or scientific fashions but by pure academic excellence. We envision papers that are exciting, clearly written, and based on original data with a clinical background. In addition to research articles, the journal provides a forum to publish both comprehensive and focused reviews.

The Journal of Experimental Orthopaedics is thought to complement the esteemed Knee Surgery, Sports Traumatology, Arthroscopy journal, which focuses on clinical investigations. When Knee Surgery, Sports Traumatology, Arthroscopy was launched in 1993, Ejnar Eriksson, its founding editor, asked the question "Why another new scientific journal when there are already so many" [23]? Now, 21 years later, KSSTA ranks among the top 33\% of journals in both Orthopaedics and Sports Sciences. I have no doubt that the Journal of Experimental Orthopaedics with its excellent Editorial Board, together with its distinguished Board of Trustees, and its committed editorial team, will similarly flourish in the wake of such visionaries like Eriksson, van Rens, and many others, and invite you to select the Journal of Experimental Orthopaedics as your first choice to publish your best orthopaedic basic research.

\section{Competing interests}

The author declares that he has no competing interests.

Received: 23 April 2014 Accepted: 8 May 2014

Published: 26 May 2014

\section{References}

1. Bland Sutton J (1897) The ligaments of the knee joint. In: Bland Sutton J (ed) Ligaments, Their Nature and Morphology, 2nd ed. vol 2. HK Lewis, London, pp 32-38

2. Madry H, Cucchiarini M, Kaul G, Kohn D, Terwilliger EF, Trippel SB (2004) Menisci are efficiently transduced by recombinant adeno-associated virus vectors in vitro and in vivo. Am J Sports Med 32(8):1860-1865

3. Kon E, Filardo G, Tschon M, Fini M, Giavaresi G, Marchesini Reggiani L, Chiari C, Nehrer S, Martin I, Salter DM, Ambrosio L, Marcacci M (2012) Tissue engineering for total meniscal substitution: animal study in sheep model-results at 12 months. Tissue Eng Part A 18(15-16):1573-1582. doi:10.1089/ten.TEA.2011.0572

4. Lindhorst E, Vail TP, Guilak F, Wang H, Setton LA, Vilim V, Kraus VB (2000) Longitudinal characterization of synovial fluid biomarkers in the canine meniscectomy model of osteoarthritis. J Orthop Res 18(2):269-280. doi:10.1002/jor.1100180216

5. Lopez-Franco M, Lopez-Franco O, Murciano-Anton MA, Canamero-Vaquero M, Herrero-Beaumont G, Fernandez-Acenero MJ, Gomez-Barrena E (2011) An experimental study of COMP (cartilage oligomeric matrix protein) in the rabbit menisci. Arch Orthop Trauma Surg 131(8):1167-1176. doi:10.1007/ s00402-011-1332-3

6. Marsano A, Vunjak-Novakovic G, Martin I (2006) Towards tissue engineering of meniscus substitutes: selection of cell source and culture environment. Conf Proc IEEE Eng Med Biol Soc 1:3656-3658. doi:10.1109/ IEMBS.2006.259748
7. Mauck RL, Martinez-Diaz GJ, Yuan X, Tuan RS (2007) Regional multilineage differentiation potential of meniscal fibrochondrocytes: implications for meniscus repair. Anat Rec (Hoboken) 290(1):48-58. doi:10.1002/ar.20419

8. McNulty AL, Guilak F (2008) Integrative repair of the meniscus: lessons from in vitro studies. Biorheology 45(3-4):487-500

9. Moriguchi $Y$, Tateishi $K$, Ando W, Shimomura $K$, Yonetani $Y$, Tanaka $Y$, Kita $K$, Hart DA, Gobbi A, Shino K, Yoshikawa H, Nakamura N (2012) Repair of meniscal lesions using a scaffold-free tissue-engineered construct derived from allogenic synovial MSCs in a miniature swine model. Biomaterials 34(9):2185-2193, doi:S0142-9612(12)01298-7

10. Setton LA, Guilak F, Hsu EW, Vail TP (1999) Biomechanical factors in tissue engineered meniscal repair. Clin Orthop Relat Res 272(367):S254-272

11. Pujol N, Tardy N, Boisrenoult P, Beaufils P (2013) Long-term outcomes of all-inside meniscal repair. Knee Surg Sports Traumatol Arthrosc. doi:10.1007/ s00167-013-2553-5

12. Kohn D (1993) Autograft meniscus replacement: experimental and clinical results. Knee Surg Sports Traumatol Arthrosc 1(2):123-125

13. Verdonk R (2010) The meniscus: past, present and future. Knee Surg Sports Traumatol Arthrosc 19(2):145-146. doi:10.1007/s00167-010-1333-8

14. Baker BM, Gee AO, Sheth NP, Huffman GR, Sennett BJ, Schaer TP, Mauck RL (2009) Meniscus tissue engineering on the nanoscale: from basic principles to clinical application. J Knee Surg 22(1):45-59

15. Goble EM, Verdonk R, Kohn D (1999) Arthroscopic and open surgical techniques for meniscus replacement- meniscal allograft transplantation and tendon autograft transplantation. Scand J Med Sci Sports 9(3):168-176

16. Arnoczky SP (1999) Building a meniscus: Biologic considerations. Clin Orthop Relat Res (367):S244-253

17. Cucchiarini M, Schetting S, Terwilliger EF, Kohn D, Madry H (2009) rAAV-mediated overexpression of FGF-2 promotes cell proliferation, survival, and alpha-SMA expression in human meniscal lesions. Gene Ther 16(11):1363-1372, doi:gt200991

18. Sonnery-Cottet B, Conteduca J, Thaunat M, Gunepin FX, Seil R (2014) Hidden lesions of the posterior horn of the medial meniscus: a systematic arthroscopic exploration of the concealed portion of the knee. Am J Sports Med 42(4):921-926, doi:0363546514522394

19. Madry H, Ziegler R, Orth P, Goebel L, Ong MF, Kohn D, Cucchiarini M, Pape D (2013) Effect of open wedge high tibial osteotomy on the lateral compartment in sheep: part I: analysis of the lateral meniscus. Knee Surg Sports Traumatol Arthrosc 21(1):39-48. doi:10.1007/s00167-012-2176-2

20. Chatain F, Robinson AH, Adeleine P, Chambat P, Neyret P (2001) The natural history of the knee following arthroscopic medial meniscectomy. Knee Surg Sports Traumatol Arthrosc 9(1):15-18

21. Englund M, Guermazi A, Lohmander LS (2009) The meniscus in knee osteoarthritis. Rheum Dis Clin North Am 35(3):579-590, doi:S0889-857X(09) 00062-3

22. van Rens TJ, van den Berg AF, Huiskes R, Kuypers W (1986) Substitution of the anterior cruciate ligament: a long-term histologic and biomechanical study with autogenous pedicled grafts of the iliotibial band in dogs Arthroscopy 2(3):139-154

23. Eriksson E (1996) Editorial. Knee Surg Sports Traumatol Arthrosc 1(1):1

\section{doi:10.1186/s40634-014-0005-x}

Cite this article as: Madry: Translating orthopaedic basic science into clinical relevance. Journal of Experimental Orthopaedics 2014 1:5.

\section{Submit your manuscript to a SpringerOpen ${ }^{\odot}$ journal and benefit from:}

- Convenient online submission

- Rigorous peer review

- Immediate publication on acceptance

- Open access: articles freely available online

- High visibility within the field

- Retaining the copyright to your article

Submit your next manuscript at $>$ springeropen.com 